\title{
Progress Report on the Canadian Multicentre Trial of Tetrahydroaminoacridine with Lecithin in Alzheimer's Disease
}

\author{
S. Gauthier, R. Bouchard, Y. Bacher, P. Bailey, H. Bergman, L. Carrier, R. Charbonneau, M. Clarfield, \\ B. Collier, D. Dastoor, L. Gauthier, M. Germain, M. Kissel, M. Krieger, S. Kushnir, A. Lamontagne, \\ J. Morin, N.P.V. Nair, L. Neirinck, J. Ratner, M. St-Martin, S. Suissa and Y. Tesfaye
}

\begin{abstract}
Since the discovery of a significant depletion of acetylcholine in discrete areas of the brain of patients affected by Alzheimer's disease, attempts at symptomatic therapy have concentrated on acetylcholine supplementation, an approach that is based upon the efficacy of dopaminergic supplementation therapy for Parkinson's disease. Choline, then lecithin, used orally, failed to improve symptoms but the hypothesis that long-term choline supplementation might stabilize the course of Alzheimer's disease remains to be tested. Nerve growth factor may also offer that possibility. Bethanechol administered intracerebroventricularly did not help when a fixed dose was used but individual titration of more selective muscarinic agonists may prove more effective. In this article we report that tetrahydroaminoacridine (THA), given together with highly concentrated lecithin, appears to bring improvement in cognition and in functional autonomy using the Mini Mental State and the Rapid Disability Rating Scale-2 respectively, without change in behavior as reflected by the Behave-AD. Double-blind cross-over studies are in progress to establish its efficacy. Improvement in study design and means of assessment of cognition, functional autonomy and behavior have been made possible by these drug trials.
\end{abstract}

\begin{abstract}
RÉSUMÉ: Rapport d'étape sur l'étude multicentrique Canadienne avec tetrahydroaminoacridine et lécithine pour la maladie d'Alzheimer. Depuis la découverte d'une perte substantcielle d'acétylcholine dans certaines régions du cerveau de patients souffrant de maladie d'Alzheimer, les essais pour traitment symptomatique ont visé à suppléer l'acétylcholine, une approche fondée sur le succès de la supplémentation en dopamine pour la maladie de Parkinson. La choline, puis la lécithine orale n'ont pas amélioré de symptômes mais l'hypothèse qu'un supplément à long-terme de choline pourrait stabiliser l'évolution de la maladie d'Alzheimer reste à vérifier. Le facteur de croissance neuronale pourrait également agir en ce sens. Le béthanéchol administré par voie intraventriculaire n'a pas aidé lorsqu'administré à une dose fixe mais une titration individuelle utilisant des agonistes muscariniques plus sélectifs pourrait s'avérer plus efficace. Dans cette publication nous rapportons que la tétrahydroaminoacridine avec lécithine hautement concentrée semble améliorer l'intellect et l'autonomie fonctionnelle tel que reflété par le Mini Mental State et la Rapid Disability Rating Scale-2 respectivement. Des études en double-insu avec chassé-croisé sont en cours pour confirmer son efficacité. Des améliorations dans le design des études et les mesures de fonctions intellectuelles, d'autonomie fonctionnelle, de comportement et d'humeur ont été rendues possibles par ces essais cliniques.
\end{abstract}

Can. J. Neurol. Sci. 1989; 16:543-546

The last ten years have seen a dramatic increase in drug trials for the symptomatic treatment of patients affected by Alzheimer's disease (AD). Most strategies have aimed to supplement brain acetylcholine (Ach) activity because of the known deficiency of that chemical transmitter in diffuse cortical areas. The approach of oral precursor loading using choline, ${ }^{1}$ then lecithin ${ }^{2}$ was well tolerated, but failed to improve significantly the symptoms of $\mathrm{AD}$. The parameters used to assess improvement consisted mostly of selected psychological tests with particular emphasis on recent memory. As a direct muscarinic ago- nist, bethanechol chloride was infused intracerebroventricularly (ICV) after the feasibility study of Harbaugh, ${ }^{3}$ but, using only one dose in all patients, there was only a minimal improvement of Mini Mental State Score found in a double-blind cross-over study involving 45 subjects. ${ }^{4}$ Higher doses in one subject later showed some positive effects on functional autonomy. ${ }^{5}$ Finally, as an inhibitor of acetylcholinesterase activity, tetrahydroaminoacridine (THA), in oral doses of up to $200 \mathrm{mg}$ a day given in association with lecithin, was reported to help patients in various stages of $\mathrm{AD} .6$

From the McGill Centre for Studies in Aging and collaborating institutions (Douglas Hospital Research Centre, Hôpital de l'Enfant-Jésus, Hôpital StLuc, Hôpital Youville, Jewish General Hospital, Maimonides Hospital for the Aged, St-John's Regional Hospital)

Reprint requests to: Dr. S. Gauthier, McGill Centre for Studies in Aging, 1650 Cedar Avenue, Montreal, Quebec, Canada H3G 1 A4 
In 1987 two multicenter studies were initiated in Canada and in the United States, to characterize better the effects of THA in AD. These studies were stopped temporarily when dose-related hepatotoxicity was found to be associated with the use of THA, in order to reassess carefully the risks versus benefits of this medication. Since 19 patients had shown statistically significant, although clinically modest, improvement in Mini Mental State (MMS), Rapid Disability Rating Scale-2, ADL portion (RDRS2), verbal word fluency and selective reminding task on THA titrated over six weeks up to a maximal dose of $200 \mathrm{mg} /$ day, ${ }^{7}$ the Canadian investigators lowered the maximal dose of THA, defined means of detecting hepatotoxicity, and redefined the cognitive, functional and behavioural parameters to use during the definitive study. The results of the 14 week titration period of this study involving 52 subjects are reported here, with particular emphasis on the MMS and RDRS-2 scores. The results of the double-blind phase of this study will be available later in the fall of 1989 .

\section{MeTHODS}

\section{Patient Population}

Fifty-two patients (25 men, 27 women, mean age 67.0, range 51 to 85 ) with a clinical diagnosis of "probable" or "definite" AD (NINCDS-ADRDA work group criteria) ${ }^{8}$ participated freely in the study. An informed consent form was signed by the patients if competent and by their curator if they were not. Patients were ambulatory and functional by themselves or with supervision by spouse or other family member. They were thus judged to be at a Stage 4 or 5 on Reisberg's Global Deterioration Scale. ${ }^{9}$ Patients with significant parkinsonian features (more than mild rigidity or akinesia), active heart disease (brady-arrhythmias), uncontrolled seizure disorder, active liver or hematological dysfunction were excluded, as well as those with Modified Ischemic Scores of 4 or more. ${ }^{10}$ Investigators at eight sites were responsible for recruitment and supervision of their patients, with common data base and procedures.

\section{Laboratory, Functional and Neuropsychological Assessments}

Besides the diagnostic procedures used for AD such as Computer Assisted Tomography (CAT) and blood screen reversible causes of dementia, ${ }^{\prime \prime}$ a complete blood count, liver function screening and EKG were done immediately prior to entry into the study. Patients were seen every two weeks at which time the following scales were administered by an investigator blind to the phase of treatment:

* Mini Mental State ${ }^{12}$

MMS

* Modified Mini Mental State ${ }^{13}$

3MS

* Rapid Disability Rating Scale ${ }_{-2}^{14}$

RDRS-2

Before and after titration, other scales used to study behavior and cognition were:

* Behave-AD 15

BEH-AD

* Hierarchic Dementia Scale 16

HDS

At each visit, patients were asked to draw a clock and set it at 11:10. A structured ADL questionnaire was filled out every week by the caregivers.

Blood was sampled every two weeks to detect early rises in serum glutamate-oxalacetate transaminase (SGOT) and/or serum glutamate-pyruvate transaminase (SGPT) levels. Blood samples for choline and THA levels were taken at selected intervals. Blood pressure, heart rate and total body weight were recorded at each visit. Specific gastrointestinal (GI), neurological or other autonomic side-effects were elicited at each visit.

\section{Drug Dose and Administration}

THA was obtained from Pharmascience Inc, Montreal, Qué., Canada, as $25 \mathrm{mg}$ capsules. Increments of $25 \mathrm{mg}$ were used during titration over eight weeks to a maximal dose of $100 \mathrm{mg}$ per day. Highly concentrated lecithin capsules (Maxicholine ${ }^{R}, 775$ $\mathrm{mg}, 75 \%$ phosphatidylcholine content) were also provided by Pharmascience Inc and ingested at mealtime throughout the study, starting two weeks prior to THA in order to avoid confusion in possible side-effects, as one capsule per meal for a week then two per meal (total daily dose of $3.4 \mathrm{~g}$ ). The highly concentrated lecithin was given instead of regular commercial lecithin (10-15\% phosphatidylcholine content) in order to increase plasma choline levels over $50 \%$ (data not shown). Patients and families were blind as to the content of the "THA capsules" during the entire study, as well as one of the investigators at each site responsible for the regular cognitive, functional and behavioral assessments. No peripheral cholinergic blocker was used in case of autonomic side-effects; in such cases the dose of THA was reduced.

\section{Data Analysis}

All data were collected and mailed to a clinical monitor at the McGill Centre for Studies in Aging, who checked the completeness of the information and stored it on soft disk using a Data Base III program. The Wilcoxon signed-rank Test was used to assess the MMS, 3MS, RDRS-2, BEH-AD and HDS scores between the various weeks of treatment (Tables 1 to 5). This test was selected because of the non-parametric nature of the scales used.

\section{RESULTS}

\section{Drop Outs}

All subjects complied with the protocol and 6 (12\%) dropped out during the 14 weeks titration period because of severe behavioural problems (2), increase of liver enzymes above the 3 times upper limit of normal threshold (2), exacerbation of asthma secondary to pulmonary infection (1), or inability to travel during winter (1). 38 subjects reached the maximal daily dose of THA $100 \mathrm{mg} /$ day in three divided doses taken at meal time; 8 subjects $(17 \%)$ were unable to exceed $50 \mathrm{mg}$ or $75 \mathrm{mg} /$ day because of GI side-effects (nausea, diarrhea, anorexia).

\section{Cognitive and Functional Changes}

There was a statistically significant improvement of the MMS score after four weeks of THA and that improvement peaked at $75 \mathrm{mg} /$ day (Table 1). Four weeks were required for patients to go back to their baseline values, suggesting some carry over effect.

The 3MS showed an identical pattern and the $8 \%$ increase between baseline and peak improvement at $75 \mathrm{mg} /$ day was the same as with the MMS (Table 2).

The RDRS-2 (ADL section) score improved after four weeks of THA and the maximal effect was seen at the dose of $75 \mathrm{mg} /$ day (Table 3). The worsening after two weeks off THA (week 12) was commented upon by most families and suggests 
a rebound effect when THA is abruptly withdrawn. A month off THA was required for patients to return to their baseline functional scores.

The BEH-AD global scores deteriorated slightly but significantly from week 0 to week 10 and to week 14 (Table 4). HDS total scores did not change during titration (Table 5).

Table 1: Summary of MMS Scores During Titration with THA/Lecithin $(\mathrm{N}=46)$

\begin{tabular}{clc}
\hline \hline Week & Treatment & MMS \\
\hline 0 & concentrated lecithin & $17.4 \pm 6.5$ \\
2 & lec + THA (25 mg/day) & $17.5 \pm 6.6$ \\
4 & lec + THA (50 mg/day) & $18.3 \pm 6.2$ \\
6 & lec + THA (75 mg/day) & $18.7 \pm 6.7$ \\
8 & lec + THA (mean dose $94 \mathrm{mg} / \mathrm{d})$ & $18.8 \pm 6.5$ \\
10 & concentrated lecithin & $18.8 \pm 6.4$ \\
12 & concentrated lecithin & $18.5 \pm 6.6$ \\
14 & & $17.6 \pm 6.7$ \\
\hline
\end{tabular}

Data expressed as units \pm SD and analysed using the Wilcoxon SignedRank Test

week $4 \mathrm{p}=0.04$ with week 0

week $6 \quad p=0.01$ with week 0

week $8 \quad p=0.01$ with week $0, p<0.01$ with week 2

$\mathrm{p}=0.01$ with week 14

week $10 p<0.01$ with week $0, p<0.01$ with week 2

$\mathrm{p}=0.04$ with week $12, \mathrm{p}=0.02$ with week 14

week $12 \mathrm{p}=0.04$ with week 0

Table 2: Summary of 3 MS Scores During Titration with THA/Lecithin $(\mathbf{N}=46)$

\begin{tabular}{clc}
\hline \hline Week & \multicolumn{1}{c}{ Treatment } & MMS \\
\hline 0 & concentrated lecithin & $53.5 \pm 20.2$ \\
2 & lec + THA (25 mg/day) & $53.9 \pm 22.0$ \\
4 & lec + THA (50 mg/day) & $55.8 \pm 21.5$ \\
6 & lec + THA (75 mg/day) & $57.2 \pm 22.3$ \\
8 & lec + THA (mean dose $94 \mathrm{mg} / \mathrm{d})$ & $57.8 \pm 22.6$ \\
10 & concentrated lecithin & $57.8 \pm 21.4$ \\
12 & concentrated lecithin & $54.7 \pm 23.1$ \\
14 & & $53.9 \pm 22.9$ \\
\hline
\end{tabular}

Data expressed as units $\pm S D$ and analysed using the Wilcoxon SignedRank Test

week $4 p=0.03$ with week 0

week $6 \mathrm{p}<0.01$ with week $0, \mathrm{p}=0.04$ with week 2

week $8 \quad p<0.01$ with week $0, p<0.01$ with week 2

$\mathrm{p}=0.02$ with week $12, \mathrm{p}<0.01$ with week 14

week $10 p<0.01$ with week $0, p<0.01$ with week 2

$\mathrm{p}=0.02$ with week $12, \mathrm{p}<0.01$ with week 14
Weekly diaries and comments from families revealed some increase in spontaneity of speech and of functional gestures (setting up table, answering phone, etc.) while on THA, and a withdrawal of these features during the wash out period.

Table 3: Summary of RDRS-2 (ADL section) Scores During Titration with THA/Lecithin $(\mathrm{N}=46)$

\begin{tabular}{clc}
\hline Week & \multicolumn{1}{c}{ Treatment } & MMS \\
\hline 0 & concentrated lecithin & $12.6 \pm 5.0$ \\
2 & lec + THA (25 mg/day) & $12.7 \pm 5.1$ \\
4 & lec + THA (50 mg/day) & $12.7 \pm 5.3$ \\
6 & lec + THA (75 mg/day) & $12.5 \pm 4.8$ \\
8 & lec + THA (mean dose $94 \mathrm{mg} / \mathrm{d})$ & $12.4 \pm 4.4$ \\
10 & concentrated lecithin & $12.6 \pm 4.8$ \\
12 & concentrated lecithin & $13.0 \pm 4.9$ \\
14 & & $12.8 \pm 4.7$ \\
\hline
\end{tabular}

Data expressed as units \pm SD and analysed using the Wilcoxon SignedRank Test

week $6 \quad p=0.03$ with week 12

week $8 \quad p=0.02$ with week $0, p=0.01$ with week 10

$\mathrm{p}=0.02$ with week 12

week $10 \quad p<0.01$ with week 12

week $12 p<0.01$ with week $0, p=0.04$ with week 14

Table 4: Behave-AD Scores During Titration with THA/Lecithin $(\mathbf{N}=\mathbf{4 3})$

\begin{tabular}{cccc}
\hline \hline Week & Treatment & $\begin{array}{c}\text { Symptoms } \\
\text { Score }\end{array}$ & $\begin{array}{c}\text { Global } \\
\text { Impression }\end{array}$ \\
\hline 0 & THA/concentrated lecithin & $5.86 \pm 5.78$ & $1.25 \pm 1.09$ \\
10 & concentrated lecithin & $6.51 \pm 5.17$ & $1.32 \pm 1.06^{*}$ \\
14 & & $5.89 \pm 5.61$ & $1.44 \pm 1.10^{* *}$ \\
\hline
\end{tabular}

Data expressed as units \pm SD and analysed using the Wilcoxon SignedRank Test

* $\quad p=0.01$ with week 0

** $\quad \mathrm{p}<0.01$ with week 0 and $\mathrm{p}=0.02$ with week 10

\begin{tabular}{ccc}
\hline \multicolumn{2}{c}{ Table 5: HDS Scores During Titration with THA/Lecithin $(\mathbf{N}=\mathbf{4 3})$} \\
\hline \hline Week & Treatment & Total HDS Score \\
\hline 0 & THA/concentrated lecithin & $144.51 \pm 29.96$ \\
10 & concentrated lecithin & $144.91 \pm 34.16$ \\
14 & & $145.39 \pm 30.49$ \\
\hline
\end{tabular}

Data expressed as units \pm SD and analysed using the Wilcoxon SignedRank Test 


\section{Discussion}

Although these results derive from a single-blind titration period, the improvement observed on THA with lecithin at the dose of 75 to $100 \mathrm{mg} /$ day could be considered significant clinically as well as statistically. Both cognitive (MMS, 3MS) and functional (RDRS-2) scales improved at a time when the patient's behavior (BEH-AD) had not. This suggests a genuine, albeit complex, effect on cognition and functional autonomy rather than a non-specific improvement of performance on testing related to a lessening of behavioral agitation.

The failure of the more detailed ( 20 items) HDS to improve on treatment may be explained by the large number of items that are still normal for the patients like those in this study at stages 4 and 5 . The HDS may prove more sensitive to treatment with patients in later stages ( 6 or 7$)$.

At the earlier stages of AD (3 and early 4), when the MMS scores are still normal, and patients have little if any impairment of ADL, scales that are sensitive to language, recent memory and spatial orientation should be used, with possibly selfanswered questionnaires on mood and anxiety levels.

The apparent rebound of functional disability after abrupt withdrawal of THA (RDRS-2 at week 12) suggests that a progressive wash out would be preferable. Finally, the previously noted $^{7}$ carry over effect of THA over one month may affect the study design of future drug trials with cognitive-enhancing agents: rapid two weeks cycles are not likely to show clear results.

The true efficacy of THA in AD remains to be assessed in the double-blind phases of the two North American studies. Even a modest improvement in cognitive and functional parameters is to be considered as clinically significant, since it might be potentiated by nicotinic or by selective muscarinic agonists, looking for the synergistic effects that have been so successful in the management of Parkinson's disease.

\section{ACKNOWLEDGEMENTS}

We thank the pharmacists of our institutions for their dedicated help throughout this study, as well as our research assistants (S. Bailey, D. Hallée, H. Laberge, A. Lagacé, M. Levine, L. Liu and M. Shugar) who carefully collected the data from patients and caregivers.

\section{REFERENCES}

1. Etienne P, Gauthier S, Johnson G, et al. Clinical effects of choline in Alzheimer's disease. Lancet 1978; 1: 508.

2. Etienne P, Dastoor D, Gauthier S, et al. Alzheimer disease: Lack of effect of lecithin treatment for 3 months. Neurology 1981; 31: 1552-1554.

3. Harbaugh RE, Roberts DW, Coombs DW, et al. Preliminary report: Intracranial cholinergic drug infusion in patients with Alzheimer's disease. Neurosurgery 1984; 15: 514-518.

4. Harbaugh RE, Reeder TM, Senter HJ, et al. Intracerebroventricular bethanechol chloride infusion in Alzheimer's disease: Results of a collaborative, double-blind study. J Neurosurg (in press).

5. Bouchard R, Gauthier L, Gauthier S, et al. Intracerebroventricular bethanechol chloride in Alzheimer's disease: Dose-related response in a patient. Can J Neurol Sci 1988; 15: 229-330.

6. Summers WK, Majoveski LV, Marsh GM, et al. Oral THA in longterm treatment of senile dementia, Alzheimer type. New Engl J Med 1986; 315: 1241-1245.

7. Gauthier S, Masson H, Gauthier L, et al. Tetrahydroaminoacridine and lecithin in Alzheimer's disease. In: Giacobini E, Becker R, eds. Current Research in Alzheimer Therapy. New York: Taylor and Francis, 1988: 237-245.

8. McKhann G, Drachman D, Folstein M, et al. Clinical diagnosis of Alzheimer's disease: Report of the NINCDS-ADRDA Work Group under the auspices of Department of Health and Human Services Task Force on Alzheimer's Disease. Neurology 1984; 34: 939-944.

9. Reisberg B, Ferris SH, De Leon MJ, et al. The global deterioration scale (GDS): An instrument for the assessment of primary degenerative dementia. Am J Psychiat 1982; 139: 1136-1139.

10. Rosen WG, Terry RD, Fuld PA, et al. Pathological verification of ischemic score in differentiation of dementias. Ann Neurol 1979; 7: $486-488$.

11. NIH Consensus Conference. Differential diagnosis of dementing diseases. JAMA 1987; 258: 3411-3416.

12. Folstein MF, Folstein SE, McHugh PR. "Mini Mental State" A practical method for grading the cognitive state of patients for the clinician. J Psychiat Res 1975; 12: 189-198.

13. Teng EL, Chui HC. The modified Mini Mental State (3MS) examination. J Clin Psychiatry 1987; 48: 314-318.

14. Linn MW, Linn BS. The rapid disability rating scale-II. J Am Geriatr Soc 1982; 30: 378-382.

15. Reisberg B, Borenstein J, Salob SP, et al. Behavioral symptoms in Alzheimer's disease: Phenomenology and treatment. J Clin Psychiatry 1987; 48: 5 [suppl]: 9-15.

16. Cole M, Dastoor D, Koszycki D. The hierarchic dementia scale. J Clin Exp Gerontol 1983; 3: 219-234. 